\title{
Transit-oriented development and ports: A national analysis in the United States
}

\author{
John Renne \\ jrenne@fau.edu \\ Florida Atlantic University
}

\begin{abstract}
This study quantified the number of fixed-transit station areas, by transit-oriented development (TOD) typology, close to major sea and river port facilities across the United States. Moreover, the study analyzed population, job, transportation, and built environment characteristics near ports. The National TOD Database was combined with the National Transportation Atlas Database, and geographic information systems analysis was utilized to isolate all stations located within a half-mile, one mile, and three miles of major ports. Findings showed that TODs are located as close as a half-mile to some of the largest ports in the United States, including Boston, Chicago, Miami, and San Francisco/Oakland. Twenty-one percent of all stations were located within three miles of major ports across the nation; thus, TODs and major ports can successfully coincide despite tensions that may arise over congestion. Few studies have examined integrated land use and transportation planning for TODs near major ports. This study recommends ideas for future quantitative and qualitative research.
\end{abstract}

\section{Article history:}

Received: November 14, 2016

Received in revised form:

October 3, 2017

Accepted: December 8, 2017

Available online: February 27, 2018

\section{Introduction}

Industrial neighborhoods near port facilities have become desirable locations for new mixed-use districts that include high-end condos and apartments, restaurants, entertainment, and shopping. Prompted by investments in urban rail, including streetcar and light rail systems, cities have experienced significant investment in warehouse district revitalizations, often in close proximity to downtown locations (Butler, 2007; Hall, 1998; Levine, 1987; Campanella \& APA Planners Press, 2010; Shaw, 2013). At the same time, port cities across the globe have seen a dramatic increase in freight and terminal operations due to increasing globalization (Read, 2004; Hesse \& Rodrigue, 2004).

Tensions over developing land near ports in transit-oriented developments (TODs) have resulted in local conflicts in some port cities, such as New Orleans. For example, the French Quarter, Marigny, Bywater, and Warehouse District neighborhoods are located within close proximity to major freight terminals along the Mississippi River and have experienced major reinvestment and gentrification, characterized by rapidly increasing property values, changing demographics, trendy new business estab-

Copyright 2018 John Renne

http://dx.doi.org/10.5198/jtlu.2018.1121

ISSN: 1938-7849 | Licensed under the Creative Commons Attribution - Noncommercial License 4.0

The Journal of Transport and Land Use is the official journal of the World Society for Transport and Land Use (WSTLUR) and is published and sponsored by the University of Minnesota Center for Transportation Studies. This paper is also published with additional sponsorship from WSTLUR. 
lishments, and residential conversions for wealthier residents and tourists. Community groups and advocates of transit and bicycling have experienced opposition for projects from the freight industry, which has been concerned about increased congestion in close proximity of the Port of New Orleans. Recent examples are illustrated by the opposition to the removal of the Claiborne Expressway, the expansion of streetcar service on St. Claude, and a lane reallocation plan on Convention Center Blvd. A separate study is underway that examines the nature of these conflicts in New Orleans from both freight and passenger perspectives, but this paper sets the stage by examining the extent of the geographic overlap of fixed-transit station, including TODs, in close proximity of major port facilities across the United States.

The following research questions explore the geographic connections between fixed-route transit stations, TODs, and their proximity to major ports across the United States. Fixed-route transit stations include approximately 90 percent rail stations, 5 percent ferry and 5 percent bus-rapid transit stations. A TOD typology, developed and applied in other studies (Renne, Tolford, Hamidi, \& Ewing, 2016), was applied to examine the transportation, population and economic characteristics of station areas near ports.

Research Questions:

1. How many fixed-transit stations, including TODs, in the United States, are located in close proximity to major port facilities?

2. What are the jobs and transportation characteristics of fixed-transit station areas by TOD typology in the last-mile of ports?

\section{$2 \quad$ Methodology}

This study examined the intersection of fixed-transit station areas within varying distances at a half-mile, 1 mile and 3 miles to major port facilities across the United States. Ports included coastal and river ports. Most were major, rated in the top 50 for tonnage and top 30 for containers (TEUs). Tables 1-3 report the rankings of the port volumes. Stations are categorized into a typology of transit-oriented developments (TODs), hybrids and transit-adjacent developments (TADs) based on walkability and density. Station areas with a Walk Score of 70 or greater and a gross housing density of greater than 8 units per acre were identified as TODs. Station areas that met one of these criteria but not the other were categorized as hybrids, and station areas that did not meet either criterion were classified as TADs. The National TOD Database identifies 4,399 stations, of which 1,443 (32.8\%) classified as TODs, 1,180 (26.8\%) as hybrids, and 1,776 (40.4\%) as TADs based on these criteria.

Data on all fixed-transit stations across the United States was obtained from the National TOD Database, which was funded by the U.S. Department of Transportation (USDOT) and was a project of the Center for Transit Oriented Development in collaboration with the Center for Neighborhood Technology, Reconnecting America and Strategic Economics. ${ }^{1}$ Data on major ports was obtained from the National Transportation Atlas Database. ${ }^{2}$ A half-mile, 1-mile and 3-mile buffer was created around all major ports to determine which station areas intersected.

\section{Results of the analysis}

\subsection{Intersection of station areas with ports by typology and region and distance}

To answer the first research question (How many fixed-transit stations, including TODs, in the United States, are located in close proximity to major port facilities?), Tables 1-3 summarize the results of the number of stations near major ports across the United States by typology. Table 1 shows that 27 stations

${ }^{1}$ http://toddata.cnt.org/

${ }^{2} \mathrm{http} / /$ wwww.rita.dot.gov/bts/sites/rita.dot.gov.bts/files/publications/national_transportation_atlas_database/2013/points.html 
across nine regions, including Boston, Chicago, Jacksonville, Miami, Nashville, New York, Pittsburgh, Portland and San Francisco, are located within a half-mile of a major port. Of these, one station is a ferry passenger terminal. When expanding the analysis to 1 mile, as shown in Table 2, 164 stations, ten of which are passenger ferry terminals, are included across 15 regions. In addition to the regions above, Buffalo, Cleveland, Norfolk, Philadelphia, San Diego, and Seattle are including. Table 3 reports that 910 station areas, which is $20 \%$ of all fixed-route transit stations in the United States, are located within 3 miles of ports. Of these, 25 are ferry passenger stations. The 910 stations are located in 20 regions, including those above as well as Kansas City, Los Angeles, Memphis, New Orleans, and St. Louis.

When examining which stations are located near ports by station typology, 15 TODs are found within a half-mile of ports, 117 are within 1 mile, and 526 are within 3 miles. There are 8, 31, and 217 hybrid stations located within a half-mile, 1 mile and 3 miles of a port, respectively; and the data shows 4, 16 and 167 TADs within a half-mile, 1 mile and 3 miles of a port, respectively. There does not appear to be any relationship between TOD typology and port volume.

When looking more closely at stations within 3 miles of a port (see Table 3), Philadelphia and San Francisco show the highest numbers with 140 and 126, respectively, followed by Boston with 71 stations. Chicago, Miami, New York, Portland each have 25 or more TODs within 3 miles of a port. Often conflicts occur in close proximity when local planners and developers are seeking to increase residential density around fixed-route transit stations near port facilities. Therefore, it might be more important from a planning perspective to look at hybrids and TADs since these stations have more potential of becoming denser in the future. Again, there does not appear to be any relationship between such stations with development potential and port tonnage or container volume.

Table 1: Stations within a half mile of major ports by region and station typology

\begin{tabular}{|l|c|c|c|c|}
\hline \multirow{2}{*}{ Region (Port Rankings) } & \multicolumn{3}{|c|}{$\begin{array}{c}\text { Number of Stations } \\
\text { (Ferry stations are in parentheses) }\end{array}$} & \multirow{2}{*}{$\begin{array}{c}\text { Total Number } \\
\text { of Stations }\end{array}$} \\
\cline { 2 - 4 } & TADs & Hybrids & TODs & \\
\hline Boston (\#39 for tonnage; \#21 for TEUs) & 0 & $2(1)$ & 4 & $6(1)$ \\
\hline Chicago (\#37 for tonnage) & 0 & 0 & 5 & 5 \\
\hline Jacksonville (\#38 for tonnage; \#17 for TEUs) & 1 & 2 & 0 & 3 \\
\hline Miami (\#11 for TEUs) & 0 & 2 & 1 & 3 \\
\hline Nashville & 0 & 1 & 0 & 1 \\
\hline New York (\#3 for tonnage; \#2 for TEUs) & 1 & 0 & 0 & 1 \\
\hline Pittsburgh (\#23 for tonnage) & 2 & 0 & 0 & 2 \\
\hline Portland (\#28 for tonnage; \#22 for TEUs) & 0 & 1 & 0 & 1 \\
\hline San Francisco/Oakland (\#34 for tonnage; \#7 for TEUs) & 0 & 0 & 5 & 5 \\
\hline Total Number of Stations & $\mathbf{4}$ & $\mathbf{8 ( 1 )}$ & $\mathbf{1 5}$ & $\mathbf{2 7}(\mathbf{1})$ \\
\hline
\end{tabular}

Note: Port rankings for tonnage by the Bureau of Transportation Statistics, 2014, available at https://www.rita.dot.gov/bts/ sites/rita.dot.gov.bts/files/publications/national_transportation_statistics/html/table_01_57.html

Port ranking for containers (TEUs) published by (Brunson, 2012). 
Table 2: Stations within 1 mile of major ports by region and station typology

\begin{tabular}{|c|c|c|c|c|}
\hline \multirow[t]{2}{*}{ Region } & \multicolumn{3}{|c|}{$\begin{array}{c}\text { Number of Stations } \\
\text { (Ferry stations are in parentheses) }\end{array}$} & \multirow[t]{2}{*}{$\begin{array}{c}\text { Total Number } \\
\text { of Stations }\end{array}$} \\
\hline & TADs & Hybrids & TODs & \\
\hline Boston (\#39 for tonnage; \#21 for TEUs) & 4 & $4(1)$ & $25(2)$ & $33(3)$ \\
\hline Buffalo & $1(1)$ & 3 & $1(1)$ & $5(2)$ \\
\hline Chicago (\#37 for tonnage) & 0 & 0 & 28 & 28 \\
\hline Cleveland (\#46 for tonnage) & 2 & 0 & 1 & 3 \\
\hline Jacksonville (\#38 for tonnage; \#17 for TEUs) & 2 & 6 & 0 & 8 \\
\hline Miami (\#11 for TEUs) & 0 & 6 & 17 & 23 \\
\hline Nashville & 0 & 1 & 0 & 1 \\
\hline New York (\#3 for tonnage; \#2 for TEUs) & 1 & 0 & 0 & 1 \\
\hline Norfolk (\#14 for tonnage; \#6 for TEUs) & 1 & 2 & 0 & 3 \\
\hline Philadelphia (\#35 for tonnage; \#14 for TEUs) & 1 & 3 & 0 & 4 \\
\hline Pittsburgh (\#23 for tonnage) & 2 & 3 & 0 & 5 \\
\hline Portland (\#28 for tonnage; \#22 for TEUs) & 1 & 1 & 0 & 2 \\
\hline San Diego (\#26 for TEUs) & 0 & $1(1)$ & $6(1)$ & $7(2)$ \\
\hline San Francisco/Oakland (\#34 for tonnage; \#7 for TEUs) & 0 & 1 & $39(2)$ & $40(2)$ \\
\hline Seattle (\#31 for tonnage; \#5 for TEUs) & $1(1)$ & 0 & 0 & $1(1)$ \\
\hline Total Number of Stations & $16(2)$ & $31(2)$ & $117(6)$ & $164(10)$ \\
\hline
\end{tabular}

Note: Port rankings for tonnage by the Bureau of Transportation Statistics, 2014, available at https://www.rita.dot.gov/bts/ sites/rita.dot.gov.bts/files/publications/national_transportation_statistics/html/table_01_57.html

Port ranking for containers (TEUs) published by (Brunson, 2012).

Table 3: Stations within 3 miles of major ports by region and station typology

\begin{tabular}{|l|c|c|c|c|}
\hline \multirow{2}{*}{ Region } & \multicolumn{3}{|c|}{ Number of Stations } & \multirow{2}{*}{$\begin{array}{c}\text { Total Number } \\
\text { of Stations }\end{array}$} \\
\cline { 2 - 4 } & TADs & Hybrids & TODs & \\
\hline Boston (\#39 for tonnage; \#21 for TEUs) & $19(2)$ & $7(1)$ & $71(3)$ & $97(6)$ \\
\hline Buffalo & $2(1)$ & 10 & $1(1)$ & $13(2)$ \\
\hline Chicago (\#37 for tonnage) & 3 & 5 & 47 & 55 \\
\hline Cleveland (\#46 for tonnage) & 17 & 19 & 3 & 39 \\
\hline Jacksonville (\#38 for tonnage; \#17 for TEUs) & 2 & 6 & 0 & 8 \\
\hline Kansas City & 1 & 17 & 0 & 18 \\
\hline Los Angeles (\#10 for tonnage; \#1 for TEUs) & 0 & 0 & 5 & 5 \\
\hline Memphis (\#41 for tonnage) & 1 & 14 & 0 & 15 \\
\hline Miami (\#11 for TEUs) & 5 & 7 & 25 & 37 \\
\hline Nashville & 0 & 1 & 0 & 1 \\
\hline New Orleans (\#7 for tonnage; \#20 tor TEUs) & 6 & 39 & 11 & 56 \\
\hline New York (\#3 for tonnage; \#2 for TEUs) & 3 & 6 & 34 & 43 \\
\hline Norfolk (\#14 for tonnage; \#6 for TEUs) & $6(1)$ & $12(2)$ & $7(3)$ & $25(6)$ \\
\hline Philadelphia (\#35 for tonnage; \#14 for TEUs) & 58 & 41 & 140 & 239 \\
\hline Pittsburgh (\#23 for tonnage) & 21 & 8 & 0 & 29 \\
\hline Portland (\#28 for tonnage; \#22 for TEUs) & 6 & 10 & 27 & 43 \\
\hline San Diego (\#26 for TEUs) & 5 & $1(1)$ & $14(2)$ & $20(3)$ \\
\hline San Francisco/Oakland (\#34 for tonnage; \#7 for TEUs) & $5(1)$ & $5(1)$ & $126(2)$ & $136(4)$ \\
\hline Seattle (\#31 for tonnage; \#5 for TEUs) & $3(1)$ & 3 & $14(1)$ & $20(2)$ \\
\hline St Louis (\#17 for tonnage) & $4(1)$ & 6 & $1(1)$ & $11(2)$ \\
\hline Total Number of Stations & $\mathbf{1 6 7}(7)$ & $\mathbf{2 1 7}(\mathbf{5})$ & $\mathbf{5 2 6 ( 1 3 )}$ & $\mathbf{9 1 0}(\mathbf{2 5})$ \\
\hline
\end{tabular}

Note: Port rankings for tonnage by the Bureau of Transportation Statistics, 2014, available at https://www.rita.dot.gov/bts/ sites/rita.dot.gov.bts/files/publications/national_transportation_statistics/html/table_01_57.html

Port ranking for containers (TEUs) published by (Brunson, 2012). 


\subsection{Ferry stations near major ports by region and station typology}

Tables 1-3 also report the number of fixed-route transit stations that are ferry stations. Boston has the only passenger ferry terminal that is located in within a half-mile of a major port. This station is categorized as a hybrid. When expanding the analysis to 1 mile (see Table 2), Boston has three ferry stations, Buffalo, San Diego and San Francisco each have two and Seattle has one. Two each are classified as TADs and hybrids and six are classified as TODs. Across the nation, 25 ferry stations are located within 3 miles of a major port (see Table 3). Of these, six each are in Boston and Norfolk, four in San Francisco, three in San Diego, and two each in Buffalo, Seattle and St. Louis. Seven ferry stations are located classified as TADs, five as hybrids, and thirteen as TODs.

\subsection{Station-area characteristics by typology}

The second research question (What are the jobs and transportation characteristics of fixed-transit station areas by TOD typology in the last-mile of ports?) is addressed by Tables $4-7$.

Table 4: Job metrics in stations within a half-mile of major ports, by station typology

\begin{tabular}{|c|c|c|c|c|}
\hline Station Typology & $\begin{array}{c}\text { Jobs Density } \\
\text { (jobs per acre) }\end{array}$ & $\begin{array}{c}\text { Percent Professional } \\
\text { Jobs }^{2}\end{array}$ & $\begin{array}{c}\text { Percent Service } \\
\text { Jobs }^{2}\end{array}$ & $\begin{array}{c}\text { Percent Other } \\
\text { Jobs }^{2}\end{array}$ \\
\hline $\begin{array}{c}\text { TODs } \\
(15 \text { stations })\end{array}$ & 189.0 & 58.9 & 35.8 & 5.3 \\
\hline $\begin{array}{c}\text { Hybrids } \\
(8 \text { stations })\end{array}$ & 62.2 & 43.4 & 42.2 & 14.5 \\
\hline $\begin{array}{c}\text { TADs } \\
(4 \text { stations })\end{array}$ & 10.8 & 51.8 & 39.6 & 8.6 \\
\hline $\begin{array}{c}\text { All Station Typologies } \\
(27 \text { stations })\end{array}$ & 125.0 & 53.2 & 38.3 & 8.5 \\
\hline
\end{tabular}

Notes: 1. Population and household data from 2010 Census; 2. Jobs Data from 2009 LED data

Table 5: Job metrics in stations within 1 mile of major ports, by station typology

\begin{tabular}{|c|c|c|c|c|}
\hline Station Typology & $\begin{array}{c}\text { Jobs Density } \\
\text { (jobs per acre) }\end{array}$ & $\begin{array}{c}\text { Percent Professional } \\
\text { Jobs }^{2}\end{array}$ & $\begin{array}{c}\text { Percent Service } \\
\text { Jobs }^{2}\end{array}$ & $\begin{array}{c}\text { Percent Other } \\
\text { Jobs }^{2}\end{array}$ \\
\hline $\begin{array}{c}\text { TODs } \\
(117 \text { stations })\end{array}$ & 185.6 & 56.1 & 37.4 & 6.6 \\
\hline $\begin{array}{c}\text { Hybrids } \\
(31 \text { stations) }\end{array}$ & 65.3 & 38.6 & 47.2 & 14.3 \\
\hline $\begin{array}{c}\text { TADs } \\
(16 \text { stations })\end{array}$ & 7.7 & 48.3 & 40.5 & 11.2 \\
\hline $\begin{array}{c}\text { All Station Typologies } \\
(164 \text { stations) }\end{array}$ & 145.5 & 52.0 & 39.5 & 8.5 \\
\hline
\end{tabular}

Notes: 1. Population and household data from 2010 Census; 2. Jobs Data from 2009 LED data 
Table 5: Job metrics in stations within 1 mile of major ports, by station typology

\begin{tabular}{|c|c|c|c|c|}
\hline Station Typology & $\begin{array}{c}\text { Jobs Density } \\
\text { (jobs per acre) }\end{array}$ & $\begin{array}{c}\text { Percent Professional } \\
\text { Jobs }^{2}\end{array}$ & $\begin{array}{c}\text { Percent Service } \\
\text { Jobs }^{2}\end{array}$ & $\begin{array}{c}\text { Percent Other } \\
\text { Jobs }^{2}\end{array}$ \\
\hline $\begin{array}{c}\text { TODs } \\
\text { (526 stations) }\end{array}$ & 98.7 & 48.4 & 41.2 & 10.4 \\
\hline $\begin{array}{c}\text { Hybrids } \\
(217 \text { stations) }\end{array}$ & 49.2 & 43.9 & 41.8 & 14.3 \\
\hline $\begin{array}{c}\text { TADs } \\
\text { (167 stations) }\end{array}$ & 5.4 & 34.4 & 47.0 & 18.5 \\
\hline $\begin{array}{c}\text { All Station Typologies } \\
\text { (910 stations) }\end{array}$ & 69.8 & 44.7 & 42.4 & 12.8 \\
\hline
\end{tabular}

Notes: 1. Population and household data from 2010 Census; 2. Jobs Data from 2009 LED data

Table 4 reports job density and job distribution within stations a half-mile of ports by station typology. Job density across all stations was more than six times the population density with 125 jobs per acre compared to 19 people per acre (not shown in table). Not surprising, TODs had a high-level job density. Somewhat unexpected, however, was the level of density at 189 jobs per acre. Jobs density falls precipitously in hybrids and TADs with 62.2 and 10.8 jobs per acre, respectively. This implies that dense housing and jobs are able to coexist in TOD locations in very close proximity to major ports. Hybrids and TADs that could develop into TODs could do so without the trade-off of residents for jobs. This is an important finding for planners trying to promote both freight and passenger solutions.

Job distribution data near major ports indicates that while professional jobs can be densely located, likely in office towers, service or other jobs near ports might require more space. Within a half-mile of all stations, 53.2 percent of jobs were categorized as professional, 38.3 percent were service jobs and 8.5 percent were categorized as other. The data does not show any patterns with regards to the types of jobs by station typology. TADs have the lowest population and jobs density but a similar distribution of employment as TODs. Hybrids, which are middle density in terms of people and jobs, have the lowest share of professional jobs and the highest share of service jobs. This could imply that TADs are truly underutilized from the perspective of maximizing the economic opportunity of highest and best land use potential. It would be useful to analyze the share of buildings devoted to warehousing but unfortunately, the dataset does not contain data on buildings. Future studies could link the national database to local data and examine the amount of building space in station areas near major ports to examine if TADs contain more warehousing. Tables 5 and 6 report similar patterns when looking at population and jobs within one and three miles of stations.

Table 7: Transportation and housing characteristics within stations 1-mile of major ports by station typology

\begin{tabular}{|c|c|c|c|}
\hline Station Typology & $\begin{array}{c}\text { Average Vehicle } \\
\text { Ownership }\end{array}$ & $\begin{array}{c}\text { Transit Commuting } \\
\text { Mode Share (\%) }\end{array}$ & $\begin{array}{c}\text { Walk and Bike Commuting } \\
\text { Mode Share (\%) }\end{array}$ \\
\hline $\begin{array}{c}\text { TODs } \\
\text { (117 stations) }\end{array}$ & 0.67 & 20.4 & 35.1 \\
\hline $\begin{array}{c}\text { Hybrids } \\
\text { (31 stations) }\end{array}$ & 0.77 & 14.8 & 20.0 \\
\hline $\begin{array}{c}\text { TADs } \\
\text { (16 stations) }\end{array}$ & 1.01 & 16.6 & 30.3 \\
\hline $\begin{array}{c}\text { All Station Typologies } \\
\text { (164 stations) }\end{array}$ & 0.72 & 19.0 & \\
\hline
\end{tabular}


For the sake of brevity, this paper reports the average vehicle ownership, transit, walk and bike commute mode shares. Vehicle ownership was 33\% lower in TOD station areas compared to TADs. The share of transit commuting was approximately $20 \%$ higher in TODs than TADs and walking and biking was more than double (see Table 7).

\section{$4 \quad$ Findings and next steps}

This study sought to address two research questions that examine the connections between fixed-route transit stations, including TADs, hybrids, and TODs across the United States with major port facilities and to examine characteristics of the station areas within close proximity.

As many as 21 percent $(910$ of 4,399) of all fixed-route transit stations intersect with major ports within a 3-mile radius of a major port.

The study found that high levels of population and housing density occur simultaneously with high levels of jobs density in station areas classified as TODs. These locations have significantly lower levels of car ownership, and higher transit and walk commuting. They also have much higher intersection density, which could indicate that such locations are likely historical districts.

Hybrids and TADs each have lower population/housing and jobs densities along with higher levels of car ownership, and lower transit and walk commuting as compared to TODs. This could indicate that TODs and major ports can coexist successfully if the goal is to stimulate higher jobs density near major ports.

The study has a number of limitations that could be addressed in future research. First, not all major ports function the same. This study included data on port volume by tonnage and containers but more data on port functions, roadway access, and intermodal shipping options could guide traffic planning at each port. Local traffic congestion is an issue and the movement of freight is often inhibited by residents and employees. However, more households, jobs, and tourists can result in increased attention and funding to build more advanced infrastructure solutions to address congestion problems. More research is needed on best practices related to integrated passenger and freight transportation solutions in congested cities near major ports. Future research could examine land uses surrounding ports.

Finally, more qualitative research is needed to better understand the role of coordinating freight and passenger stakeholders to conducted integrated land use and transportation planning in station areas in close proximity to major ports. This topic is the subject of a related forthcoming study on this topic. Understanding the scope and nature of this topic, along with the local context for solutions in each city is vital, given our economy will likely continue to globalize and our cities will continue to urbanize. 


\section{References}

Brunson, P. (2012, May). Top 30 U.S. ports: Finding the right balance [Special supplement]. Logistics Management, 50a-55a.

Butler, T. (2007). Re-urbanizing London docklands: Gentrification, suburbanization or new urbanism? International Journal of Urban and Regional Research, 31(4), 759-781.

Campanella, R., \& APA Planners Press. (2010, March). Delta urbanism and New Orleans: Before. Places Journal. Accessed 18 Jan 2018. https://doi.org/10.22269/100329

Hall, C. (1998). The politics of decision making and top-down planning: Darling Harbour, Sydney. In D. Tyler, M. Robertson, \& Y. Guerrier (Eds), Managing tourism in cities: Policy, process and practice (pp. 9-24). Chichester: John Wiley.

Hesse, M., \& Rodrigue, J.-P. (2004). The transport geogrpahy of logistic and freight distribution. Journal of Transport Geography, 12(3), 171-184.

Levine, M. (1987). Downtown redevelopment as an urban growth strategy: A critical appraisal of the Baltimore renaissance. Journal of Urban Affairs, 9(2), 103-123.

Read, R. (2004). The implications of increasing globalization and regionalism for the economic growth of small island states. World Development, 32(2), 365-378.

Renne, J., Tolford, T., Hamidi, S., \& Ewing, R. (2016). The cost and affordability paradox of transitoriented development: A comparison of housing and transportation costs across transit-oriented development, hybrid and transit-adjacent development station typologies. Housing Policy Debate, 26(4-5), 819-834.

Shaw, K. (2013). Docklands dreamings: Illusions of sustainability in the Melbourne docks redevelopment. Urban Studies, 50(11), 2158-2177. 